\title{
誘導加熱によるSUJ2鋼のオーステナイト化における 炭化物の溶解の速さに対する冷間加工の影響
}

\author{
結城 敬史 ${ }^{1) *} \cdot$ 高田 翔太 ${ }^{1)}$ \\ Effect of Cold Deformation Prior to Induction Heating Austenitization on Dissolution Speed of Carbide in SUJ2 Steel \\ Hiroshi YUKI and Shota TAKADA
}

Synopsis : The effect of prior cold deformation on the dissolution speed of carbide in SUJ2 bearing steel subjected to induction heating austenitization at $920^{\circ} \mathrm{C}$ was examined. Microscopic observations using scanning electron microscopy and transmission electron microscopy, in addition to crystallinity measurements using powder X-ray diffraction, found no trace of the cold deformation effect in the carbide and few crystal defects in the spheroidal carbide particles of an as-received specimen. However, it is important to note that the cold deformation resulted in a refinement of austenite grains during austenitization, which accelerated the dissolution of chromium from the carbide compared to an unprocessed specimen. This led to enhancement of the resultant carbon diffusion in a matrix.

The volume fraction of carbide present at grain boundaries was estimated assuming a simple geometrical model. The relationship between the holding time and the volume fraction of undissolved carbide was derived based on a bulk diffusion model of chromium into an austenite matrix. Experimental results on the dissolution speed of carbide were qualitatively explained by considering the combination of grain boundary diffusion and bulk diffusion. The austenitization behavior of SUJ2 steel is remarkably influenced by the microstructure, in particular for short austenitization times.

Key words : bearing steel; SUJ2; heat treatment; induction heating; cold deformation; carbide dissolution.

\section{1. 緒言}

転がり軸受にはJIS G $4805 ： 2008$ に規定されるSUJ2鋼 を一般的に用いる。通常, 熱処理工程に打ける加熱は䨌囲 気を管理した炉の中で行うが，著者らは省エネルギー化や 低環境負荷などの観点から誘導加熱によるプロセスを検討 している。

焼入れ時の焼入れ温度と残留炭化物量が熱処理後の軸受 特性に大きく影響する。このためまず，球状化焼なましが 行われた状態でのSUJ2鋼に対して誘導加熱による均熱温 度 $900,950,1000^{\circ} \mathrm{C}$ の場合におけるオーステナイト化の保 持時間と残留炭化物量の関係を調査し, この温度域での保 持時間に対する焼入れ後の残留炭化物量を予測する実験式 を作成した ${ }^{1)}$ 。次に，炉で加熱する場合と同等以上の軸受 特性となるような焼入れ温度と残留炭化物量の範囲を見出 した ${ }^{2)}$ 。そのような範囲となるオーステナイト化条件は上 記の実験式に基づき決定できる。しかし，なんらかの要因 が働くことで炭化物の溶解の速さが大きく変わるとすれ ば, このオーステナイト化条件での焼入れ後の残留炭化物 量は適切な值とはならない。
たとえば，オーステナイト化前に行われる軸受部品の成 形工程においては, 切削加工以外に冷間加工を用いること がある。冷間加工による焼入れ後の性質への影響を詳細に 報告したのはBeswickが初めてであり ${ }^{3)}$, 冷間加工された SAE52100鋼を 830 $860^{\circ} \mathrm{C}$ でオーステナイト化すると未加 工の場合に比べて炭化物の溶解が加速されることを示し た。冷間加工によりフェライト結晶粒内に転位のセル構造 が形成され, オーステナイト化の昇温過程でサブグレイン 化が起こり, サブグレインと炭化物の間の界面が増加する ことでオーステナイトの生成核が増加し, その結果として オーステナイト結晶粒が微細化するとともにオーステナイ トの生成時に炭化物の溶解が加速することを結論付けた。

この炭化物の溶解に関係して, マトリクスのオーステナ イト化の様式が均熱温度により違うことに注意しなければ ならない。オーステナイト化前に行われた球状化焼なまし のためにマトリクス中にはCがほとんど存在しない。この

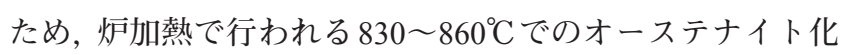
の場合では炭化物から拡散で Cが供給されることにより

$$
\alpha[\text { フェライト }]+C[\text { セメンタイ }] \rightarrow \gamma[\text { オーステナイ }]
$$

平成30年3月27日受付 平成30年6月22日受理＼cjkstart平成30年7月21日J-STAGE早期公開 (Received on Mar. 27, 2018; Accepted on Jun. 22, 2018; J-STAGE Advance published on Jul. 21, 2018)

1) NTN (株) 先端技術研究所 (Advanced Technology R\&D center, NTN Corporation, 5-105 Hidamarinooka Kuwana Mie 511-0867)

* Corresponding author : E-mail : hiroshi_yuuki@ntn.co.jp

DOI : https://doi.org/10.2355/tetsutohagane.TETSU-2018-039 
の変態が起こる。炭化物を包み込むようにシェル形のオー ステナイト結晶粒が形成され，式 (1) の変態が完全に完了 した後もオーステナイト中へCがさらに溶解することで, マトリクス中のC 濃度が高くなる $\left(\right.$ 文献 $^{4)}$ の Fig.1における Type I )。これに対して, 誘導加熱により $910^{\circ} \mathrm{C}$ 以上の高温 まで急速加熱する場合では, 炭化物が溶解し始める時点で のマトリクスはオーステナイトであり，この中を炭化物か ら溶解したCが拡散することでマトリクス中のC濃度が高 くなる (文献 ${ }^{4)}$ の Fig.1における Type V)。

$$
\gamma[\text { 低炭素 }]+C[\text { セメンタイ }] \rightarrow \gamma[\text { 高炭素 }]
$$

Beswickが行った実験では式 (1) のオーステナイト化の 様式であるのに対して，著者らが検討している誘導加熱に よるプロセスでは式 (2) の様式であるため, 事前の冷間加 工により炭化物の溶解が加速するかは明らかではない。さ らに, Beswick は別報 ${ }^{5)}$ で炭化物の溶解に対する炭化物中 の $\mathrm{Cr}$ の役割の重要性を指摘しているが, 文献 ${ }^{3)}$ では冷間加 工による炭化物の溶解の加速について Crに関連付けた記 述はない。著者らはむしろ体拡散と粒界拡散によるマトリ クス中への $\mathrm{Cr}$ の溶解機構が本質であり ${ }^{5)}$, 炭化物の溶解の 加速はその結果であると考えている。

本研究では球状化焼なましが行われた未加工材とこれに 冷間加工した試料に対して誘導加熱により $920^{\circ} \mathrm{Cでのオー}$ ステナイト化を行い, 残留炭化物量を比べた。その結果, 冷間加工した試料において炭化物の溶解が加速される現象 が認められた。このため, 構成要素である炭化物とマトリ クスに分けて組織を調べ，オーステナイト化の過程での炭 化物の溶解に対する両者の挙動の役割について考察を試み た。マトリクスの粒界上にある炭化物の粒界拡散による溶 解機構の可能性を議論した。

\section{2. 実験方法}

\section{$2 \cdot 1$ 試料の作製方法}

購入したままの未加工材および未加工材を 2 通りの圧下 率で冷間加工した試料の合計 3 種類の試料に対して 3 通り の保持時間でオーステナイト化を施した。

$2 \cdot 1 \cdot 1$ 試料の成形方法

大同特殊鋼 (株) より購入した未加工材は球状化焼なま しをした直径 $75 \mathrm{~mm}$ の棒材であり, Table 1 に示す化学成 分である。この棒材から内径 $54.6 \mathrm{~mm}$, 外径 $62.6 \mathrm{~mm}$, 高さ $17.6 \mathrm{~mm}$ のリング形状の試料を旋盤により削り出し, 未加

Table 1. Chemical composition of SUJ2 steel used in the present study (mass \%).

\begin{tabular}{c|c|c|c|c|c|c|c|c}
\hline $\mathrm{C}$ & $\mathrm{Si}$ & $\mathrm{Mn}$ & $\mathrm{P}$ & $\mathrm{S}$ & $\mathrm{Ni}$ & $\mathrm{Cr}$ & $\mathrm{Mo}$ & $\mathrm{Cu}$ \\
\hline 1.02 & 0.31 & 0.41 & 0.008 & 0.003 & 0.07 & 1.33 & 0.03 & 0.08 \\
\hline
\end{tabular}

\section{工材試料とした。}

次に，鍛造により冷間加工された試料の作製において は, まず内径 $42.4 \mathrm{~mm}$, 外径 $52.4 \mathrm{~mm}$, 高さ $17.2 \mathrm{~mm}$ と内径 $28.9 \mathrm{~mm}$, 外径 $42.3 \mathrm{~mm}$, 高さ $17.2 \mathrm{~mm}$ のリング形状の試 料を削り出した。その後, 鍛造によりいずれもが内径 54.6 $\mathrm{mm}$, 外径 $62.6 \mathrm{~mm}$, 高さ $17.6 \mathrm{~mm}$ となるように成形した。 鍛造前の半径方向の肉厚がそれぞれ $5.0 \mathrm{~mm}$ と $6.7 \mathrm{~mm}$ であ るのに対して鍛造後にはともに $4.0 \mathrm{~mm}$ であり, 肉厚減少 率が $20 \%$ と $40 \%$ であるために，以後これらをそれぞれ圧下 率 $20 \%$ の試料と圧下率 $40 \%$ の試料と呼ぶことにする。

$2 \cdot 1 \cdot 2$ 誘導加熱によるオーステナイト化の方法

成形された試料を誘導加熱によりオーステナイト化し た。誘導加熱装置の詳細は前報に記したとおりであり ${ }^{1)}$, リングの外径面と内径面に溶接した熱電対によりオーステ ナイト化中の試料の温度をモニターした。オーステナイト 化の温度を $920^{\circ} \mathrm{C}$, 保持時間を $0 \mathrm{~s}, 10 \mathrm{~s} し く は 40 \mathrm{~s}$ に設定 し，試料を所定の保持時間だけオーステナイト化した後， 水を噴射することで急冷した。

\section{$2 \cdot 2$ 試料の評価方法}

未加工材，未加工材を冷間加工した試料およびこれらを オーステナイト化した試料において, 熱電対を溶接した箇 所の近くの部分からリングに対して半径方向に研削切断す ることで薄板を切り出した。その薄板を樹脂埋めした後に 切断面をダイヤモンド懸濁液による研磨で鏡面仕上げし， 切り出しによる損傷層を除去した。

\section{$2 \cdot 2 \cdot 1$ 鏡面仕上げされた薄板の評価法}

電界放出型の走査型電子顕微鏡 $(\mathrm{SEM})$ により鏡面仕上 げされた表面を調べた。電子線の加速電圧は $1.0 〜 1.5 \mathrm{kV}$ と し, 2 次電子像もしくは反射電子像を観察した。2次電子像 においてはこの加速電圧に対してマトリクスと炭化物の明 るさの差が最も大きくなり，マトリクスが明るく見え，炭 化物が暗く見える。さらに，エレクトロンチャネリング効 果により結晶方位に起因するコントラストをマトリックス 内に観察することができる。

また, 光学顕微鏡により表面を観察し, 交点切断法によ り ASTM規格で規定された結晶粒度を測定した。オーステ ナイト化後の試料においてはピクリン酸を主成分とする腐 食液に浸すことでマトリクスの粒界を現出させた。この試 料からは旧オーステナイト結晶粒の粒度が得られ, 炭化物 が溶解する過程でのマトリクスの結晶粒の寸法の目安とな る。一方，オーステナイト化前の試料に抢いてはこの方法 では粒界が明瞭に観察されなかったため, 高周波グロー放 電によるスパッタリング処理 ${ }^{6)}$ を施した。この試料からは フェライト結晶粒の粒度が得られ, マトリクスの初期の粒 度を意味する。

\section{$2 \cdot 2 \cdot 2$ 炭化物の評価方法}

炭化物の粒子を評価するため, 鏡面仕上げされた薄板試 料を電解研磨し, 炭化物をマトリクスから抽出分離した。 
純水 $200 \mathrm{~mL}$ に濃塩酸 $2 \mathrm{~mL}$ を加えた液を電解液として電解 研磨は電圧 $0.5 \mathrm{~V}$ で行った。陰極側の対向電極はステンレ ス板とした。薄板の表面に炭化物が残され，これを分離し た。この炭化物の粒子に対して誘導結合プラズマ (ICP) 発 光分光による分析, X線回折 (XRD) による測定, SEM お よび透過型電子顕微鏡 (TEM) による観察を行った。

ICP 発光分光による分析に拈いては抽出した炭化物を酸 分解法およびアルカリ溶融分解法により処理することで測 定溶液を調製し，分析に供した。XRDによる測定において は $\mathrm{Cu}-\mathrm{K} \alpha$ 線を線源とし, $\theta-2 \theta$ 法で $20^{\circ} \leqq 2 \theta \leqq 80^{\circ}$ の範囲を $0.01^{\circ}$ のステップ角で走査した。また，TEMによる観察にお いては電子線の加速電圧を $300 \mathrm{kV}$ とした。

\section{3. 結果}

\section{$3 \cdot 1$ オーステナイト化前の試料中の炭化物}

$2 \cdot 1 \cdot 1$ の Table 1 に示した未加工材の組成において, C と Crがマトリクスにほとんど存在せず，炭化物として析 出していると仮定すると, 炭化物の組成は $\left(\mathrm{Fe}_{0.9} \mathrm{Cr}_{0.1}\right)_{3} \mathrm{C}$ となり, Crの質量分率は 8.75 mass\%である。一方, ICP 発 光分光分析から測定された $\mathrm{Cr}$ の質量分率は $9.3 \mathrm{mass} \%$ で あった。したがって, Cr はマトリクス中にほとんど分配 されず，炭化物中に濃縮されていた。また，Crがすべて 炭化物中に存在し，炭化物とマトリクスの密度をそれぞ れ $7680 \mathrm{~kg} / \mathrm{m}^{3}, 7860 \mathrm{~kg} / \mathrm{m}^{3}$ とすると, 炭化物の体積分率は $15.5 \mathrm{vol} \%$ となる。

未加工材から抽出された炭化物の粒子のSEMによる観 察の結果を Fig.1（a）に示す。寸法には広い分布があり, 形 状に関してもほほ球形から細長い楕円体のような形状まで 様々であった。このため, 個々の炭化物の粒子の投影面積 $s\left(\mathrm{~m}^{2}\right)$ を等しい面積の円で置き換え, $r_{\mathrm{eq}}=\sqrt{s / \pi}(\mathrm{m})$ を相 当円半径として, Fig.1（b）と（c）においては $0.05 \mu \mathrm{m}$ の刻 み幅で $r_{\mathrm{eq}}$ に対する分布を示した。Fig.1（b）において，粒子 の個数 $n$ としてみた場合には $r_{\mathrm{eq}}$ が大きくなると頻度が急激 に小さくなるが, $0.7 \mu \mathrm{m}$ 付近に頻度の極大が存在する。さ らに, $n$ に粒子の体積 $4 \pi r_{\mathrm{eq}}{ }^{3} / 3$ を掛けて体積の比率としてみ ると Fig.1（c）のようになり，それぞれ約 $0.7 \mu \mathrm{m}$ と約 $0.5 \mu \mathrm{m}$ が最大となる2つのピークの重ね合わせであることがはつ きりとわかる。

球状化焼なましの溶体化の過程では炭化物をすべて溶 解することはせず，炭化物の粒子が部分的にマトリクス中 に残った状態とする。したがって, 徐冷の過程で未溶解炭 化物が成長核となるような炭化物が存在する。これとは別 にマトリクス中で新たに核生成一成長する炭化物が存在 する。このように，炭化物には2つの由来があり, Fig.1 (c) に拈けるピークはそれぞれに対応する。量的にはほぼ同じ オーダであり，実質的にいずれもが炭素の供給源として作 用していると考えられる。
一方, Fig.2には個々の炭化物をTEMにより観察した結 果を示す。Fig.2（a）に示す明視野像ではバックグラウンド が明るいために炭化物の内部の様子をほとんど透視する ことはできないが, Fig.2（b）に示す暗視野像では炭化物の 内部に格子欠陥のコントラストが観察されないことがわか る。このようにほとんどの炭化物の粒子に打いて格子欠陷 は存在しなかった。

XRDで測定されたすべての回折ピークは $\mathrm{Fe}_{3} \mathrm{C}$ (格子定 数 $a=0.5091 \mathrm{~nm}, b=0.67434 \mathrm{~nm}, c=0.4526 \mathrm{~nm}, P n m a$ 斜 方晶）で指数付けすることができ, 回折角の測定值と計算 值の差は $0.1^{\circ}$ 以下であった。したがって, $\mathrm{Fe}_{3} \mathrm{C}$ の $\mathrm{Fe}$ が $\mathrm{Cr}$ で かなり置換されても, 測定精度の範囲内において炭化物の 格子定数に有意な変化は生じなかった。

次に, 冷間加工後に抽出した炭化物の粒子に対しても同 様の評価を行ったが，圧下率 $20 \%$ の試料と圧下率 $40 \%$ の試 料のいずれにおいても未加工材試料の結果と顕著な差は認 められなかった。SEMによる観察において，炭化物が割れ たり砕けたりしているような痕跡はほとんど認められな かった。TEMによる観察においても，炭化物に格子欠陷が 導入された様子はなかった。XRDで測定された回折ピーク は同じ格子定数で指数付けされ, 回折ピークの回折角がシ フトする，もしくは幅が広くなるようなことはなかった7)。

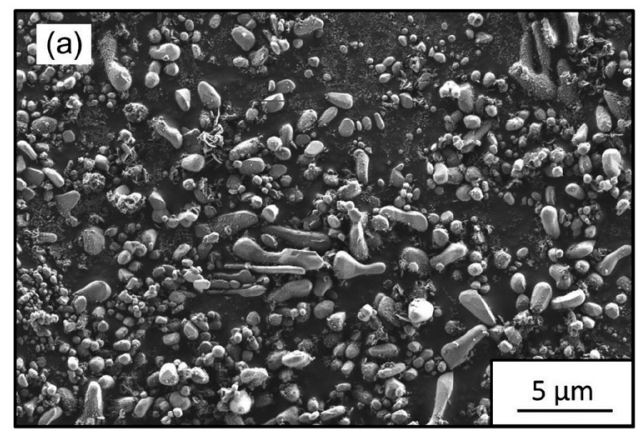

(b)

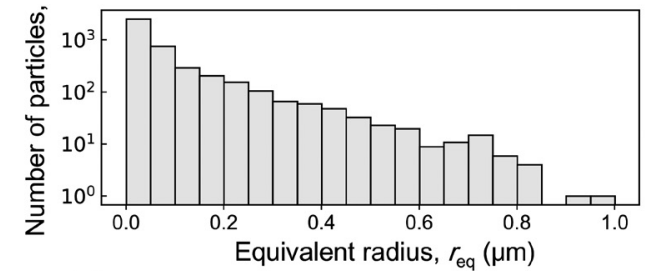

(c)

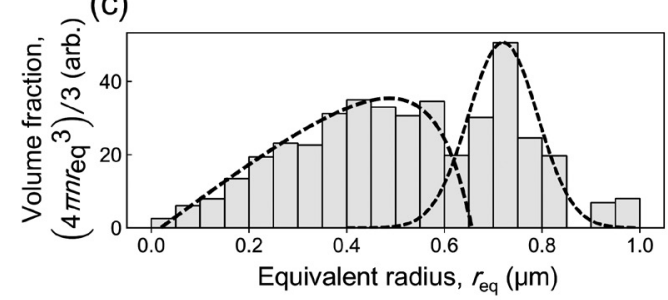

Fig. 1. SEM micrograph and corresponding size distribution of extracted carbide particles from an as-received specimen of (b) number $n$ and (c) volume ratio $4 \pi n r_{\mathrm{eq}}{ }^{3} / 3$, respectively. 
したがって，本節の SEM，TEMおよびXRDによる評価 の限りに扔いて、鍛造により未加工材に冷間加工を施して も炭化物には変化が起こっていないことが結論される。

\section{$3 \cdot 2$ 未加工材試料の組織}

未加工材試料における鏡面仕上げされた表面の2次電子 像を Fig.3に示す。形状と寸法ともに様々な炭化物の粒子 の断面が視野内にほぼ一様に現れ, 粒界上に優先的に存在 する，もしくは欠乏する傾向がないことがこの像からわか る。

粒界上にある炭化物の全体に対する体積率を見積もるた め, 以下の簡単なモデルを考える。マトリクスの結晶粒は 半径 $R(\mathrm{~m})$ の球形であるとし, その中に半径 $r_{i}(\mathrm{~m})$ の球形

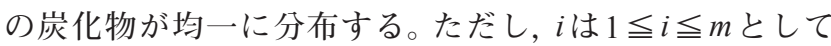

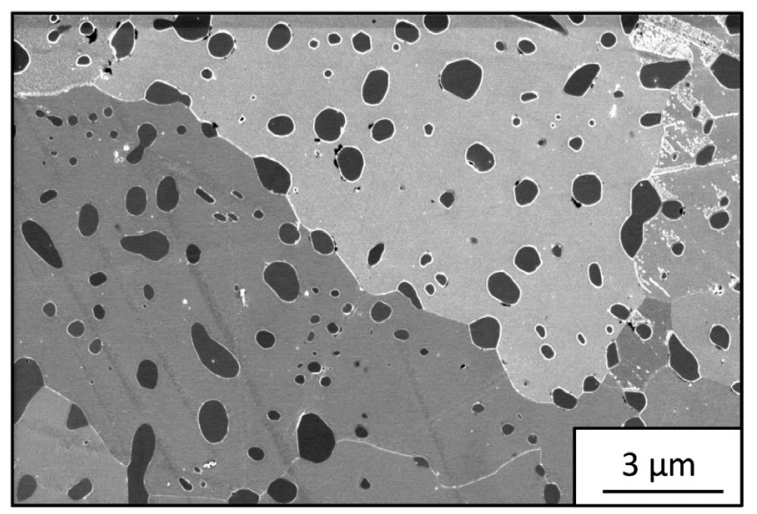

Fig. 3. SEM micrograph of mirror-polished surface of asreceived specimen.
大小様々な炭化物が含まれ，半径 $r_{i}$ の炭化物の単位体積あ たりの個数は $n_{i}\left(\mathrm{~m}^{-3}\right)$ であるとする。

半径 $r_{i}$ の炭化物の中心と結晶粒の中心の距離が $R-r_{i}$ 以 上で $R+r_{i}$ 以下の場合には炭化物は結晶粒の表面と交わ る。したがって, 結晶粒の内部にある炭化物の個数は

$$
N_{i}=\frac{4 \pi R^{3} n_{i}}{3}
$$

であるが, 粒界上にある炭化物の個数は, $r_{i} \ll R$ として

$$
N_{i}^{G B}=\frac{4 \pi\left\{R^{3}-\left(R-r_{i}\right)^{3}\right\} n_{i}}{3} \fallingdotseq 4 \pi R^{2} r_{i} n_{i}
$$

のように近似的に表される。 $i$ に関する総和を取り, 粒界上 にある炭化物の全体に対する体積率 $F$ は

$$
F=\frac{\sum_{i=1}^{m} N_{i}^{G B} v_{i}}{\sum_{i=1}^{m} N_{i} v_{i}}=\frac{3 \sum_{i=1}^{m} r_{i} n_{i} v_{i}}{R \sum_{i=1}^{m} n_{i} v_{i}}
$$

となり，ここで $v_{i}$ は半径 $r_{i}$ の炭化物の体積であるために

$$
F=\frac{3 \sum_{i=1}^{m} n_{i} r_{i}^{4}}{R \sum_{i=1}^{m} n_{i} r_{i}^{3}}
$$

となる。したがって，このモデルでは $F$ は $R$ に反比例し，具 体的に測定された Fig.1（b）の分布を使って総和を計算す ると, 本研究で使用した未加工材に対しては

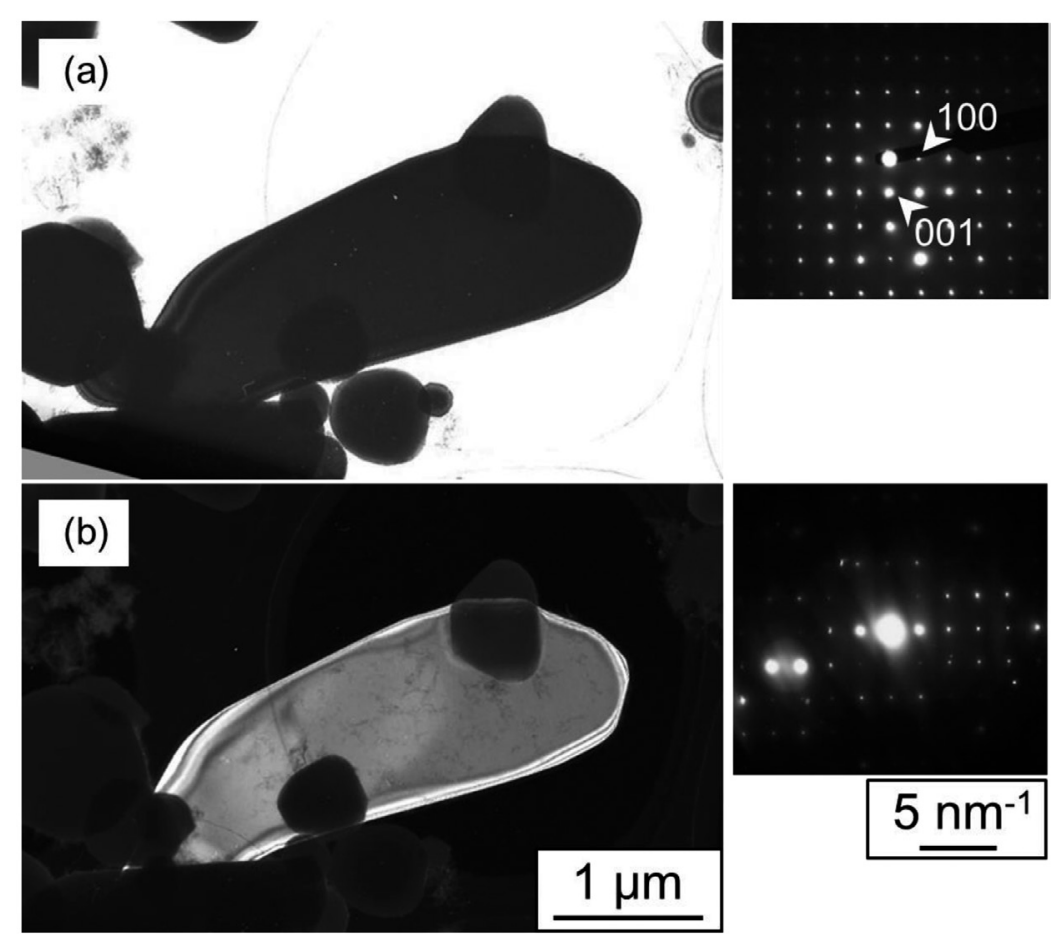

Fig. 2. (a) Bright-field and (b) dark-field TEM micrographs of an extracted carbide particle from an as-received specimen. Incidence beam direction is close to [010] of the Pnma (No.62) orthorhombic structure with lattice parameters of $a=0.5091 \mathrm{~nm}, b=0.67434$ $\mathrm{nm}, c=0.4526 \mathrm{~nm}$. 


$$
F=\frac{1.76 \times 10^{-6}}{R}
$$

である。たとえば結晶粒径が $10 \mu \mathrm{m}$ であるとすると, $R=5$ $\times 10^{-6} \mathrm{~m}$ であるために $F$ は 0.352 となる。

\section{$3 \cdot 3$ 冷間加工した試料の組織}

オーステナイト化前の圧下率 $20 \%$ の試料に打ける鏡面 仕上げされた表面の2 次電子像を Fig.4に示す。冷間加工前 の試料と比べて炭化物の分布の状況にはほとんど違いが なかった。しかし，マトリクス中に炭化物とほほ同じ程度 の寸法のモザイク模様のコントラストがみられた。圧下率 $40 \%$ の試料に打いても同様にモザイク模様のコントラスト がみられたことから, 冷間加工で導入された多量の転位が 七ル状に配列し網目状構造が形成されていると考えられ る。

ただし，この構造はオーステナイト化の昇温過程の途中 で回復するため ${ }^{3)}$, 炭化物の溶解が加速される現象の主な 原因ではないと考える。

\section{$3 \cdot 4$ オーステナイト化後の試料の組織}

未加工材試料, 圧下率 $20 \%$ の試料打よび圧下率 $40 \%$ の試 料に対して, 温度 $920^{\circ} \mathrm{C}$, 保持時間 $10 \mathrm{~s}$ でオーステナイト化 を施した。試料を鏡面に仕上げた後, $2 \cdot 2 \cdot 1$ で述べた方 法によりマトリクスの粒界を現出させた表面を光学顕微鏡 により観察した。その結果を Fig.5 (a)〜 (c) に示し, 比較 のためオーステナイト化前の未加工材試料の結果を Fig.5 （d）に揭げる。これらの像から測定された粒度平均結晶粒 径 ${ }^{8)}$ の換算值を Fig.6にまとめる。

オーステナイト化前の未加工材試料のマトリクスの粒 度番号は 8.5 であったが，これに保持時間が $10 \mathrm{~s}$ のオース テナイト化を施すと変態により粒度番号は 10.6 となった。 これに対して, 冷間加工を施した試料の粒度番号は 11.1 と 11.7 となり, 未加工の試料より微細化した。4・2で後述す るように, 冷間加工によりマトリクスの結晶粒内に転位の セル構造が形成され，オーステナイト化の昇温過程の途中 で回復することによりフェライトのサブグレイン化が起

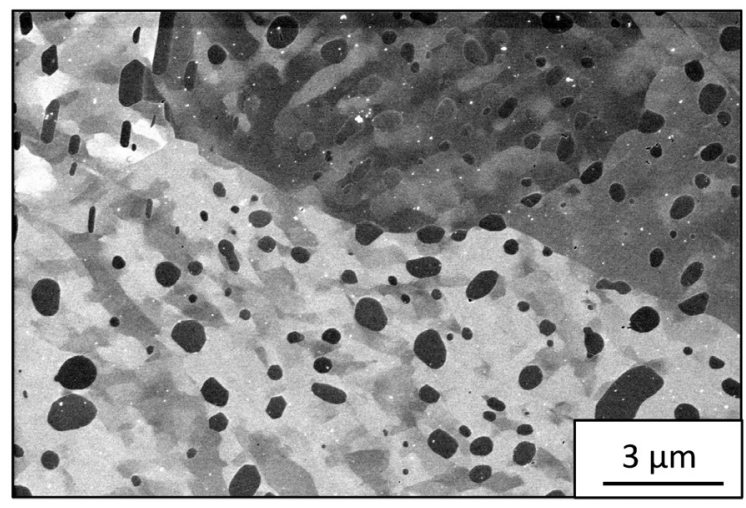

Fig. 4. SEM micrograph of mirror-polished surface of asworked specimen ( $20 \%$ reduction).
こった影響であると考えられる。

また，これらのすべての試料において保持時間を $10 \mathrm{~s}$

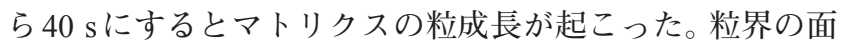
積を減少させることや粒界面の曲率半径を大きくすること が粒成長の駆動力となるため, 元のマトリクスの粒度が大 きいほど粒成長は速くなる。したがって, オーステナイト 化の昇温過程の途中でその前に施された冷間加工の影響が 回復により完全に消滅するのではなく, オーステナイト化 の保持時間に対する粒度の変化に圧下率が影響する。

次に，これらの試料の鏡面仕上げされた表面における炭 化物をSEMにより観察した結果を Fig.7 (a)〜 (c) に示し, 比較のためオーステナイト化前の未加工材試料の結果を Fig.7 (d) に揭げる。像中に占める炭化物の断面の面積比率 は, オーステナイト化前の未加工材試料に比べてオーステ

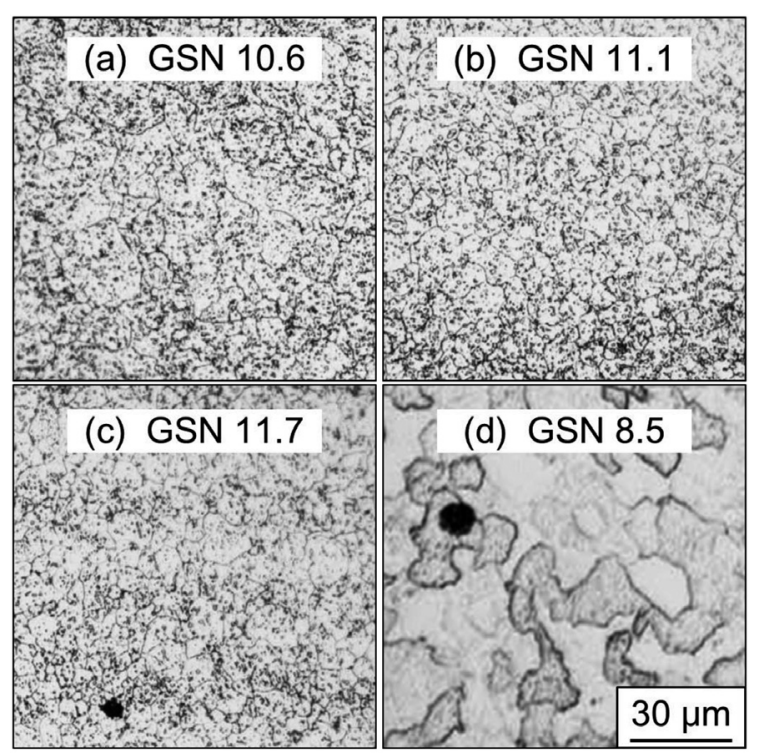

Fig. 5. Optical micrographs of picral-etched surface for specimens austenitized for $10 \mathrm{~s}$ at $920^{\circ} \mathrm{C}$. Prior cold deformation: (a) unworked, (b) $20 \%$ and (c) $40 \%$ reduction. An as-received specimen is shown in (d) for comparison.

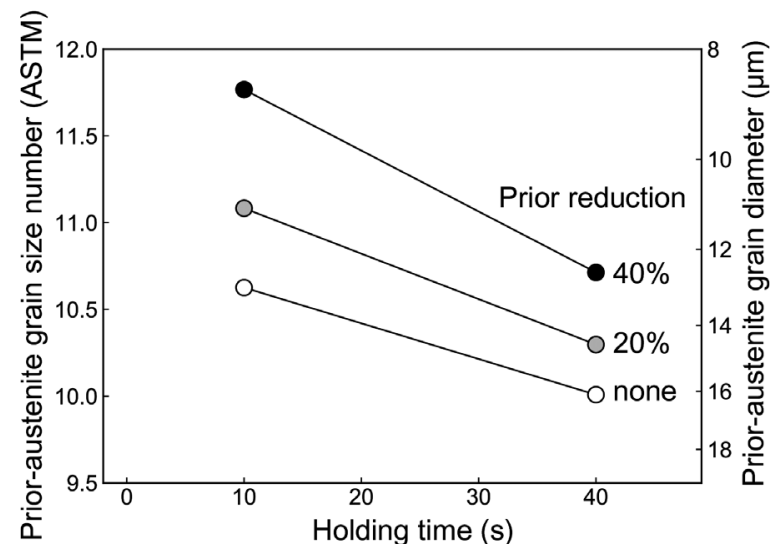

Fig. 6. Influence of cold working and austenitization conditions on prior-austenite grain size. 
ナイト化後に減少するが，オーステナイト化後のそれぞれ の試料の間でも圧下率により減少の程度が異なる。オース テナイト化中に炭化物が溶解する速さが異なることが示唆 される。

これらの像を2值化処理し, 炭化物の断面の面積比率 を算出した。この值を残留炭化物量とみなし, 残留炭化 物量に対する圧下率やオーステナイト化の保持時間の影 響をFig.8に示す。なお，オーステナイト化前の炭化物量 $18.9 \mathrm{vol} \%$ を図中にメ印で記入した。未加工材試料におい て，0 s の保持時間に対して残留炭化物量は $12.9 \mathrm{vol} \%$ に急 激に減少するが，それより長い保持に対しては保持時間の 平方根に対して線形に減少する。一方，冷間加工した試料 に扎いて $10 \mathrm{~s}$ と $40 \mathrm{~s}$ のいずれの保持時間に対しても圧下率

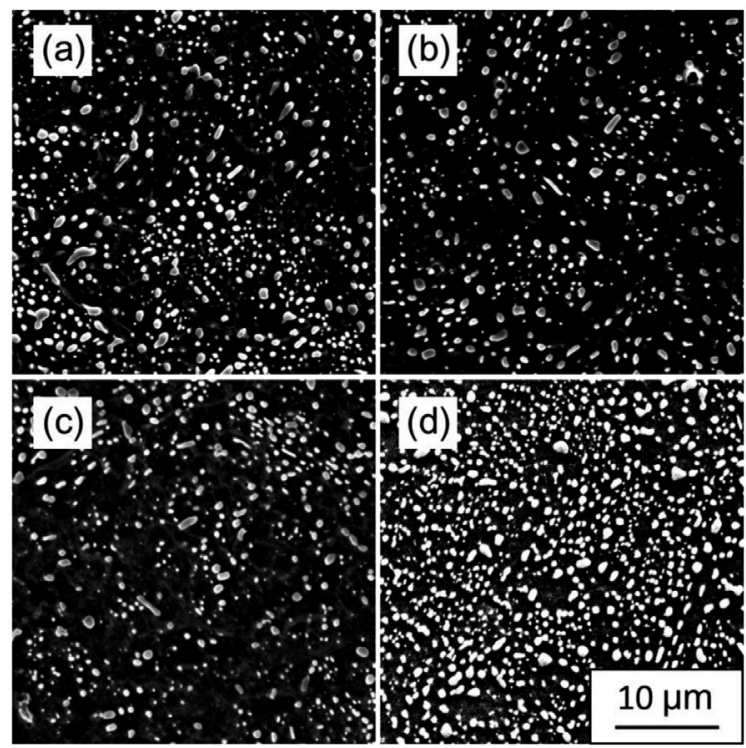

Fig. 7. SEM micrographs of mirror-polished surface for specimens austenitized for $10 \mathrm{~s}$ at $920^{\circ} \mathrm{C}$. Prior forming: (a) unworked, (b) 20\% and (c) 40\% reduction, respectively. An as-received specimen is shown in (d) for comparison.

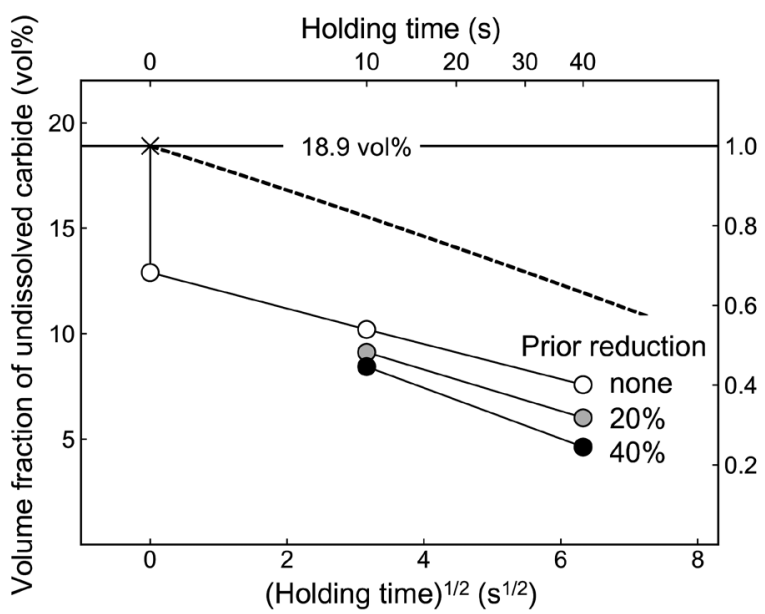

Fig. 8. Influence of cold working and austenitization conditions on volume fraction of undissolved carbide.
が高くなるほど炭化物の溶解が加速され，冷間加工による 影響が明らかに認められる。そして，3・1で述べたように 冷間加工により炭化物に変化が起こっていないことから, 炭化物の溶解が加速される現象にはこれが溶解していくマ トリクスに原因があると考えられる。実際，オーステナイ 卜化の保持時間が同一の試料の間で，Fig.6では圧下率が大 きいほど粒度番号が大きく，一方でFig.8では圧下率が大 きいほど炭化物の溶解が加速されている。

さらにFig.7 (a)〜 (c) に打いてはオーステナイト化後に 急冷したために試料のマトリクスはマルテンサイトであ り，これのコントラストが邪魔をして図中での旧オーステ ナイト結晶粒界を識別することは困難であった。このた め，粒度の測定に用いた腐食後の試料をSEMにより観察 した。Fig.9には圧下率20\%の試料において保持時間が $10 \mathrm{~s}$ のオーステナイト化を施した試料の観察例を示す。

Fig.3に示した未加工材の場合と比べて，粒度が大きく なっているにもかかわらず粒界上もしくはその近傍での炭 化物が結晶粒の内部に比べてまばらである傾向がみられ る。また, Fig.9 (a) の低倍率像中に矢印で示す粒界上にあ る炭化物をFig.9 (b) に拡大するが, 侵食されることで内部 に穴があいていることがわかる。隣接するオーステナイト 結晶粒の間の粒界上にある炭化物に扎いて, 粒界面と炭化
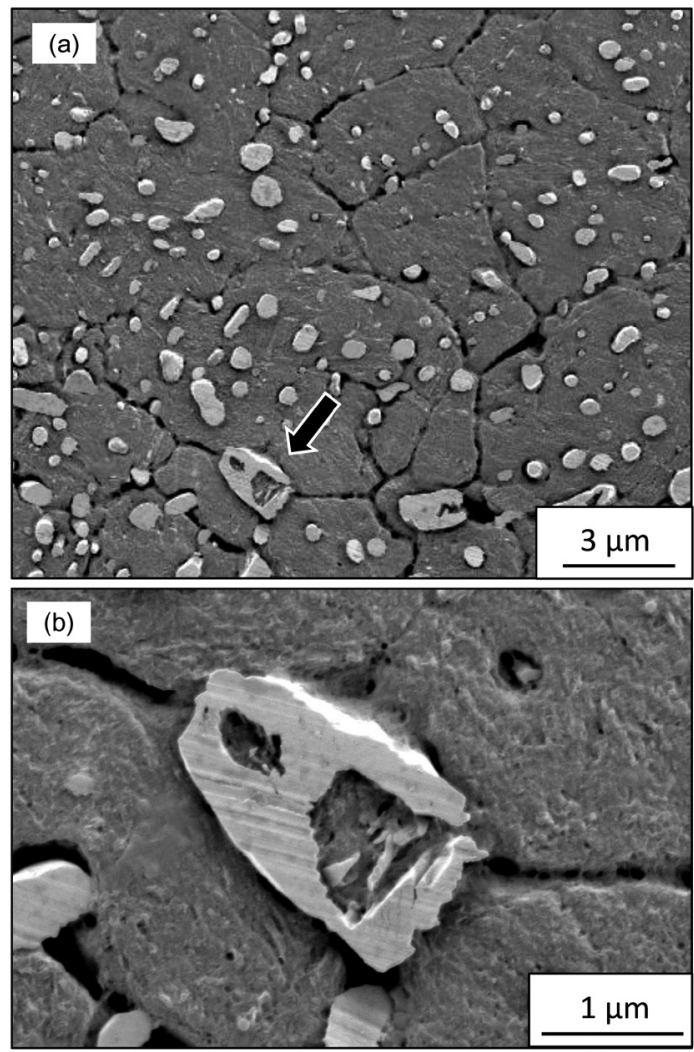

Fig. 9. SEM micrograph of picral-etched surface subsequent to mirror polishing in specimen austenitized for $10 \mathrm{~s}$ after undergoing $20 \%$ reduction. The arrow in panel (a) points to an eroded particle lying on a grain boundary. (b) Magnified image of eroded particle. 
物の交線上の3重点で粒界拡散によりその箇所が急激に溶 解することでくびれを起こしたことが考えられる。この形 態を持つ炭化物はオーステナイト化を施したすべての試料 においてまれにみられ，主に粒界上に存在し，結晶粒の内 部には存在しなかった。そして, 未加工材を冷間加工した だけの試料ではこの形態を持つ炭化物はまったくみられな かった。したがって，この現象は冷間加工ではなくオース テナイト化の影響であり，4・3に後述するように，結晶粒 の内部にある炭化物と粒界上にある炭化物では溶解の速さ が違うためであると推測される。

\section{4. 考察}

\section{$4 \cdot 1$ 炭化物に関する考察}

炭化物がマトリクスに埋め込まれた状態で冷間加工され ると，塑性変形もしくはフラグメント化することがある。 ただし, これらのことは炭化物の形態が層状の場合で起 こり7), 球状化されている場合には炭化物は弾性変形する にとどまる9)。さらに，炭化物の Feが Crにより置換される と, 強加工に対しても変形による組織変化が炭化物にみら れないことが報告されている ${ }^{10)}$

本研究における炭化物でも塑性変形もしくはフラグメン 卜化の痕跡は認められず，オーステナイト化前の冷間加工 による影響を受けていなかった。つまり，冷間加工の有無 によらずオーステナイト化前での炭化物の状態はすべての 試料でほぼ同じであり，炭化物自身の内在的な要因が炭化 物の溶解を加速するのに関与しているのではない。

\section{$4 \cdot 2$ マトリクスに関する考察}

Beswickによれば ${ }^{3}$ ，球状化焼なましが行われた試料を冷 間加工すると，マトリクスの結晶粒内に転位の七儿構造が 形成される。これに熱処理を施すと $450^{\circ} \mathrm{C}$ 程度で回復を始 め, サブグレイン化による結晶粒の微細化が起こる。 $\mathrm{A}_{\mathrm{cl}}$ 点 の直下まで加熱しても微細化の影響が残り，結晶粒径はお およそ $1 \mu \mathrm{m}$ である。これに対して，冷間加工を施していな い試料を熱処理した場合には球状化焼なまし後の粒度を反 映して結晶粒径はおおよそ $12 \mu \mathrm{m}$ となる。

本研究に打いてはオーステナイト化の温度を $920^{\circ} \mathrm{C} に$ 設 定したが，Fig.6で示したように，やはり冷間加工に由来す る微細化の履歴をオーステナイト結晶粒が引き継いだ。未 加工の試料に比べて圧下率が大きくなるにつれて旧オース テナイト結晶粒の粒度番号は大きくなった。

\section{$4 \cdot 3$ マトリクス中への炭化物の溶解に関する考察}

$\mathrm{Fe}_{3} \mathrm{C}$ の溶解に比べて $\mathrm{Cr}$ 含㟔炭化物の溶解の速さは遅 い。マトリクス中での $\mathrm{Cr}$ の置換型拡散が $\mathrm{C}$ の格子間型拡散 にくらべて困難で, 全体としてこれが炭化物の溶解を律速 しているためであると考えられている ${ }^{5)} \mathrm{Cr}$ とCの親和力 は大きく，まず炭化物とマトリクスの界面で炭化物が分解 してCrがマトリクスに拡散した後に, 残されたCはマトリ
クス中を高速拡散することができる11)。これにより，オー ステナイト化の過程に扎いて炭化物の表面の近傍に Crに 富んだ領域が形成されるが，Cは高速拡散によりマトリク 又全体に広がり，ほぼ均一に分布すると考えられる。しか し, 以下に述べる簡単なモデルより, Fig.8に示した残留炭 化物量の実験結果の傾向を $\mathrm{Cr}$ のマトリクス中への体拡散 だけでは説明できないことがわかる。

半径 $r_{0}(\mathrm{~m})$ の球形の炭化物の粒子が無限に大きいマトリ クスの中にあり, $\mathrm{Cr}$ が半径方向に拡散すると考える。オー

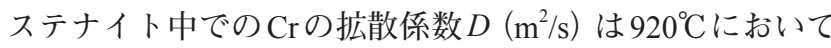
$4.65 \times 10^{-17} \mathrm{~m}^{2} / \mathrm{s}$ であるとする ${ }^{12)}$ 。また, 炭化物とマトリク スの界面に打いて局所平衡が成り立ち，さらに界面に打け るマトリクス側の $\mathrm{Cr}$ 濃度は常に $C_{0}\left(\mathrm{~kg} / \mathrm{m}^{3}\right)$ であるとする。 Fig.1 (c) の結果を参照して, 炭化物の粒子の半径は $r_{0} \fallingdotseq$ $0.5 \mu \mathrm{m}$ であるとして見積もる。

実際, 保持時間を $t(\mathrm{~s})$ とした場合の拡散長が $\sqrt{D t}$ で与え られるとすると, $t=40 \mathrm{~s}$ の場合に拡散長は $0.043 \mu \mathrm{m}$ とな り, 近接する炭化物の粒子との距離は $1 \mu \mathrm{m}$ 程度以上であ るため, 互いのCrの拡散層は干渉しない。したがって, こ のモデルでの無限に大きいマトリクスの設定は妥当である と考えられる。ただし，炭化物が溶解するにつれて炭化物 の粒子は小さくなるためにマトリクスと炭化物の界面は移 動するが, 半径は $r_{0}$ のままで変わらないとする。

マトリクス中の $\mathrm{Cr}$ 濃度 $C\left(\mathrm{~kg} / \mathrm{m}^{3}\right)$ に関する拡散方程式は 3次元極座標により

$$
\frac{\partial C}{\partial t}=D \frac{1}{r^{2}} \frac{\partial}{\partial r}\left(r^{2} \frac{\partial C}{\partial r}\right)
$$

と書かれ，ここで $r(\mathrm{~m})$ は炭化物の中心からの距離である。 この方程式は無次元化された半径 $\rho=r / r_{0}$ と時間 $\tau=D t / r_{0}{ }^{2}$ により

$$
\frac{\partial C}{\partial \tau}=\frac{1}{\rho^{2}} \frac{\partial}{\partial \rho}\left(\rho^{2} \frac{\partial C}{\partial \rho}\right)
$$

となる。

3・1で述べたように，オーステナイト化前に打いてマト リクス中の $\mathrm{Cr}$ 濃度はほぼ 0 であるため, オーステナイト化 の初期条件は $\left.C\right|_{\tau=0}=0$ とする。一方, 炭化物とマトリクス の界面に打ける境界条件は時刻に依らず $\left.C\right|_{\rho=1}=C_{0}$ と仮 定している。式 (6) の解は相補誤差関数を用いて

$$
C=\frac{C_{0}}{\rho} \operatorname{erfc}\left(\frac{\rho-1}{2 \sqrt{\tau}}\right) .
$$

となる。

マトリクス中の $\mathrm{Cr}$ 濃度を体積積分すると溶解した $\mathrm{Cr}$ の 質量 $m(\mathrm{~kg})$ が得られる。 $r$ に関する積分範囲を $r_{0} \leq r<\infty$ と することで, 


$$
\begin{aligned}
& m=\iiint C d v=\iiint C r^{2} \sin \theta d r d \theta d \phi=4 \pi \int_{r_{0}}^{\infty} r^{2} C d r \\
& =4 \pi r_{0}^{3} \int_{1}^{\infty} \rho^{2} C d \rho
\end{aligned}
$$

となるため, 式 $(7)$ を代入して, $\mathrm{s}=(\rho-1) / 2 \sqrt{\tau}$ と変数 変換すると

$$
\begin{aligned}
& \frac{m}{4 \pi r_{0}^{3}}=\int_{1}^{\infty} \rho^{2} C d \rho=C_{0} \int_{1}^{\infty} \rho \operatorname{erfc}\left(\frac{\rho-1}{2 \sqrt{\tau}}\right) d \rho \\
& =C_{0} \int_{0}^{\infty}(2 \sqrt{\tau} s+1) \operatorname{erfc}(s)(2 \sqrt{\tau} d s) \\
& =C_{0}\left(4 \tau \int_{0}^{\infty} s \operatorname{erfc}(s) d s+2 \sqrt{\tau} \int_{0}^{\infty} \operatorname{erfc}(s) d s\right)
\end{aligned}
$$

であり, $\int_{0}^{\infty} s \operatorname{erfc}(s) d s=1 / 4, \quad \int_{0}^{\infty} \operatorname{erfc}(s) d s=1 / \sqrt{\pi}$ である ために

$$
\frac{m}{4 \pi r_{0}^{3}}=C_{0}\left(\tau+\frac{2}{\sqrt{\pi}} \sqrt{\tau}\right)=C_{0}(\tau+1.13 \sqrt{\tau})
$$

となる。

一方，オーステナイト化前に打ける炭化物の粒子中の $\mathrm{Cr}$ の質量 $m_{0}(\mathrm{~kg})$ は, Table 1に示した組成から炭化物の密度 を $7680 \mathrm{~kg} / \mathrm{m}^{3}$ として

$$
m_{0}=\frac{4 \pi r_{0}^{3}}{3} \times 7680 \times 0.0875=\frac{4 \pi r_{0}^{3}}{4.46 \times 10^{-3}}(\mathrm{~kg})
$$

である。したがって，拡散により溶解した $\mathrm{Cr}$ の質量比率は $m / m_{0}$ であり, これは溶解した炭化物の体積比率に相当する ので, 残留炭化物量 $x$ (vol\%) は, Fig.8において測定された 未加工材試料の炭化物の体積分率が 18.9 vol\%であること から,

$$
x=18.9\left(1-\frac{m}{m_{0}}\right)=18.9\left\{1-4.46 \times 10^{-3} C_{0}(\tau+1.13 \sqrt{\tau})\right\} \cdots \cdots
$$

と表される。

熱力学平衡計算ソフトウェア FactSageによる $\mathrm{Fe}-\mathrm{Cr}-\mathrm{C}$ 系

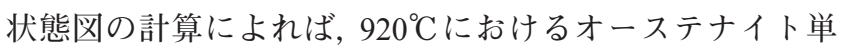
相領域とオーステナイトー炭化物二相領域の境界線に関し て, C 濃度が低い場合には Cr 濃度は $10 \mathrm{mass} \%$ 前後である が, C濃度が高くなるとともに $\mathrm{Cr}$ 濃度は低くなり, C濃度 が 1.2 mass\%において Cr濃度は 0 となる。したがって, 保 持時間が短い期間においてはマトリクスに溶解している C 濃度が低いために, 炭化物とマトリクスの界面に打けるマ トリクス中の $\mathrm{Cr}$ 濃度を 10 mass\%であると仮定すると， マ トリクスの密度を $7860 \mathrm{~kg} / \mathrm{m}^{3}$ として, 式 (8) 中の $C_{0}$ は $C_{0}=$ $78.6 \mathrm{~kg} / \mathrm{m}^{3}$ となる。また, $r_{0} \fallingdotseq 0.5 \mu \mathrm{m}, D=4.65 \times 10^{-17} \mathrm{~m}^{2} / \mathrm{s}$ であるため, 式 (8) 中の $\tau=D t / r_{0}{ }^{2}$ は $\tau=t / 5376$ となる。この 場合の式（8）で表される保持時間と残留炭化物量の関係を Fig.8中に破線で描いた。横軸を時間の平方根として表示す
ると式 (8) は上向きに凸な関数であるが, 実際には $\tau$ の項 は $\sqrt{\tau}$ の項に対して小さいために, わずかに正に偏倚した 直線となる。したがって, 体拡散では残留炭化物の保持時 間に対する依存性が下向きに凸な曲線になることはなく， 実験結果の傾向と一致していない。つまり，保持時間が短 い期間においては別の溶解機構が同時に作用し, 炭化物の 溶解が加速されていることになる。

以上の考察は炭化物がマトリクスの結晶粒の内部にあ る場合のことであり，粒界上にある場合には状況がかなり 違ってくる。粒界が高速拡散の経路となり, Crが炭化物か ら粒界面へ拡散し, この速度は体拡散の場合に比べて桁違 いに速い ${ }^{13)}$ 。このため, 粒界上にある炭化物の溶解は結晶 粒の内部にある場合より速い。実際, 粒界上にある炭化物 の体積率を $F$ として, 保持時間がごく短い期間にこの炭化 物が完全に溶解することで消失したとすると，その後は結 晶粒の内部にある炭化物の溶解のみとなり, 式 (8) より残 留炭化物量は

$$
\begin{aligned}
& x=18.9(1-F)\left\{1-4.46 \times 10^{-3} C_{0}(\tau+1.13 \sqrt{\tau})\right\} . \\
& \fallingdotseq 18.9(1-F)\left(1-5.93 \times 10^{-3} C_{0} \sqrt{\tau}\right)
\end{aligned}
$$

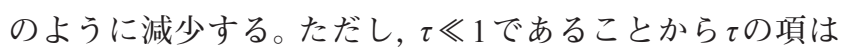
$\sqrt{\tau}$ の項に対して小さいために無視した。

結晶粒径が $10,15,20 \mu \mathrm{m}$ の場合において粒界上にある 炭化物の体積率は式 (5) より $F=0.352,0.235,0.176$ であ る。同様に $C_{0}=78.6 \mathrm{~kg} / \mathrm{m}^{3}, \tau=t / 5376$ として, 均熱保持を 開始してから $0.1 \mathrm{~s}$ の間に粒界上にある炭化物がすべて溶 解するとした場合における式（9）で表される保持時間と 残留炭化物量の関係を Fig.10に示した。保持時間がごく短 い期間に全体に対する体積率 $F$ に相当する炭化物が溶解

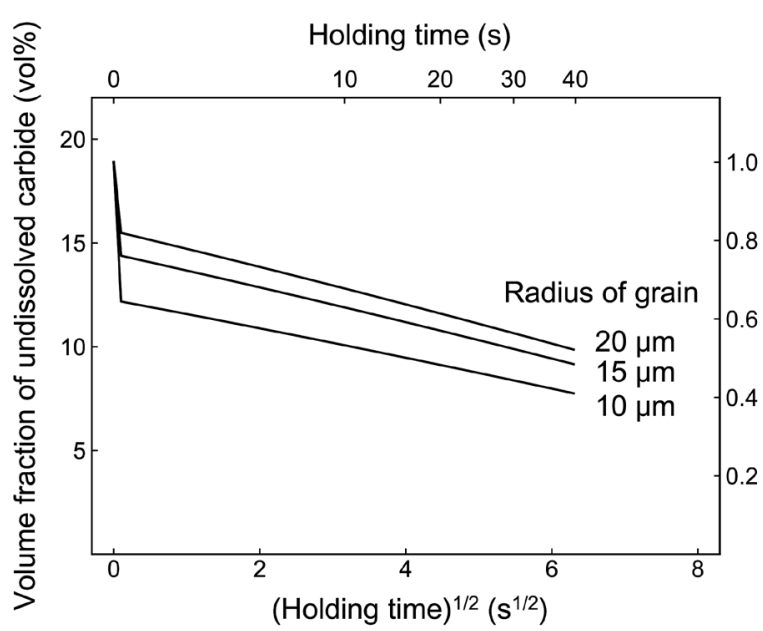

Fig. 10. Relationship between holding time and volume fraction of undissolved carbide for combined bulk diffusion and grain boundary diffusion model. The dissolution of carbide at grain boundaries was assumed to take place within $0.1 \mathrm{~s}$ and be linear with the square root of the holding time. 
する。その後は結晶粒の内部にある炭化物の溶解に移行す る。残留炭化物量は保持時間の平方根に対して線形に依存 し，ほぼ同じ傾きで減少する。これはFig.8に示した実験結 果の傾向を概ね説明する。

最後に, Fig.8において未加工材の炭化物の体積分率 18.9 vol $\%$ が， $920^{\circ} \mathrm{C}$ で $0 \mathrm{~s}$ の保持時間に対して残留炭化物量 $12.9 \mathrm{vol} \%$ に減少した。このことは設定温度である $920^{\circ} \mathrm{C} に$ 達した時点ではすでに元の炭化物の状態が凍結されず, 昇 温過程の途中で粒界上にある炭化物が溶解することで消失 したことに対応すると考えられる。実際, 熱電対によりモ ニターされた試料の温度より, $920^{\circ} \mathrm{C}$ 付近での昇温速度は 本研究に扎いて $20^{\circ} \mathrm{C} / \mathrm{s}$ 程度であり, この程度の昇温速度で はCrの粒界拡散に追いつかない。したがって, この結果か らは高速な $\mathrm{Cr}$ の粒界拡散が実験的に検証されていないた め, 今後, マトリクス内の炭化物の近傍および粒界面の近 傍での Cr濃度を調査するなどの別の手段により間接的な 証拠を積み重ねることでこれを証明する必要がある。

\section{5. 結言}

SUJ2鋼の球状化焼なましが行われただけの未加工材と これに $20 \%$ もしく $40 \%$ の圧下率で冷間加工を施した試 料に対して誘導加熱により $920^{\circ} \mathrm{C}$ でオーステナイト化を 行った。炭化物の溶解が始まる時点でマトリクスはオース テナイトに変態した状態である。保持時間を $0 \mathrm{~s}, 10 \mathrm{~s} も し$ くは $40 \mathrm{~s}$ とて, 残留炭化物量を比べた。

（1）未加工材に冷間加工を施しても炭化物には変化が起
こっていない。したがって, 炭化物自身が炭化物の溶 解を加速するのに関与しているのではない。

（2）冷間加工を施していない試料と比べて, 冷間加工を施 した試料をオーステナイト化するとオーステナイト化 の過程でマトリクスの組織が微細化する。これにより 粒界上にある炭化物の体積率が高くなる。

（3）粒界上にある炭化物は粒界拡散するため, 粒内にある 炭化物が体拡散する場合に比べて溶解が速い。このた め, 未加工の試料に比べて, 冷間加工を施した試料で は保持時間が短い期間において炭化物の溶解が大きく 加速されると考えられる。

\section{文献}

1) H.Yuki, M.Sato and C.Ohki: Tetsu-to-Hagané, 103(2017), 194

2 ) H.Yuki, M.Sato and C.Ohki: Tetsu-to-Hagané, 104(2018), 98.

3 ) J.Beswick: Metall. Trans. A, 15(1984), 299.

4 ) M.Hillert, K.Nilsson and L.-E.Torndahl: J. Iron Steel Inst., 209(1971), 49

5 ) J.M.Beswick: Metall. Trans. A, 18(1987), 1897.

6 ) T.Mitani: Bunseki Kagaku, 57(2008), 859.

7 ) H.Omura, K.Furusawa and K.Tanaka: J. Jpn. Inst. Met., 36(1972), 1151.

8 ) J.H.Hensler: J. Inst. Met., 96(1968), 190.

9 ) D.V.Wilson: Trans. Am. Soc. Met., 47(1955), 321.

10) A.Inoue, T.Ogura and K.Masumoto: Bull. Jpn. Inst. Met., 13(1974), 653.

11) K.Seto: Tetsu-to-Hagané, 46(1960), 976.

12) H.Oikawa: Tetsu-to-Hagané, 68(1982), 1489.

13) Y.Iijima, H.Nitta, R.Nakamura, K.Takasawa, A.Inoue, S.Takemoto and Y.Yamazaki: J. Jpn. Inst. Met., 69(2005), 321. 